\title{
China's Foreign Policy and its Choice for Cultural Soft Power: The Tools
}

\author{
Saifur Rahman ${ }^{1 *}$ \\ ${ }^{1}$ East China Normal University, Department of Politics, 3663 North Zhongshan Road, Shanghai, China.
}

KEYWORDS

Soft power

Cultural Soft Power

Foreign Policy

Tools of Soft Power

\author{
ABSTRACT
}

Chinese soft power can be assessed in many aspects because there are several tools in which soft power can manifest. This article seeks to assess the efficiency of China's soft power using four tools from the perspective of public diplomacy. The analysis helps us to better understand the efficiency of foreign public communication tools. The paper is mainly qualitative research from collected secondary materials, following Mark Leonard's (2002) concept of three dimensions of public diplomacy. The tools considered are: the Confucius institute (cultural institutes); Belt and Road initiative summit 2017 (international events); China central television/CCTV (media); International Students (financial aid for researchers and students). The analysis uses the three dimensions of public diplomacy: daily communication, strategic communication, and long-term communication. There is no indication that any of the selected four tools resonates with any of the three dimensions of public diplomacy. Some tools resonate more than others with a particular dimension of public diplomacy, but nothing is set in place. The media use daily communication quite effectively. International events are more so in strategic communication. Both international students and the cultural institute have an advanced role in long-term communication. However, the three dimensions are important to asses expected outcomes in foreign relations. A single tool could not effectively serve all concerns for getting support within the international community. The limitations of a tool can curb its appeal for a particular dimension, while advantages of the same tool spring in another.

\footnotetext{
*Contact address: saifur.rahman27@yahoo.com (S. Rahman).
} 


\section{Introduction}

This article examines China's use of various cultural soft power tools and their effectiveness in communicating a positive perception of China in international relations. In general, many scholars discuss the resources, limitations, and characteristics of soft power and its tools. However, this research views soft power not through a critical lens, but rather aims to understand the benefits of how each tool can be used to serve the interest of the state. Recently, China has attracted more global attention by introducing different institutions and initiatives in their foreign policies. Soft power strategies can be used to counter (political backlash) and can also reveal misconceptions about China. Soft power is central to understanding international relations but the difficulties are: (a) to identify the sources of soft power, (b) to identify the process of the operation of soft power, and (c) to understand the conditions so policies can be mobilized (Roselle, Miskimmon and O'Loughlin 2014).

Flew (2016) stated that China have used a number of communication tools to connect with the foreign public in recent years. China built the Confucius Institute to promote Chinese language and culture. It has hosted international events such as the Beijing Olympics in 2008, the Shanghai World Expo in 2010, among others. China has promoted international student and researcher exchanges. It has also developed mass media such as China Central Television (CCTV). In entertainment media, it promoted co-production arrangements such as films with Hollywood and online games (Flew 2016). We can see that China has applied various tools of soft power. This may raise the question-which tools are effective for Chinses foreign public communication?

The assessment of effectiveness of tools can contribute in the policy and scholar spectrums. China needs a systematic public diplomacy with Chinese characteristics, because it is relatively weak (Wang 2008). The advantages of particular tools are important to understand because it helps policymakers to understand how soft power can be used to achieve its intended objective. This paper contributes to existing scholarly research on the topic, as it assesses the effectiveness of tools, and provides insight into why China has utilized a 
variety of soft power tactics. This paper also utilizes the perspective of public diplomacy, because China has tried to receive attention from international actors for their role in interpersonal relations. Thus, the need to develop trust and understanding with others through strategic or nonstrategic dialogue is most important (Lanteigne 2009). Public diplomacy can build trust and bridges with foreigners (Taylor 2010). The discussion will be followed by Mark Leonard's (2002) three dimensions of public diplomacy, and the effectiveness of soft power tools regarding those three dimensions.

\section{Theoretical framework}

\section{Foreign Policy, Soft Power and the Chinses Perspective}

Chinese foreign policy has been shaped by different leaders since the foundation of the Peoples' Republic of China (PRC) in 1949. China's foreign policy has gone through several reforms. According to Lanteigne (2009), during the Mao era, Chinese foreign policy was guided by five principles: peaceful co-existence, mutual respect of each sovereignty, non- interference, non- aggression, and mutual benefit. Despite having few diplomatic relations at that time, China was still involved in various international political issues. Under Deng Xiaoping, China began it opening up and reform period. In this period, massive reforms were implemented to begin the transformation of an isolated China to becoming a rising power. A majority of significant foreign policies from Jiang Zemin focused on diplomacy especially with the United States and Russia. President Hu Jintao introduced the concept of peaceful development and a harmonious world in his policies. He began to build more cross regional diplomacy ties with Europe, Africa, and Latin America among others. He emphasized the importance of soft power, identified the sources of Chinese soft power and cultivated their role in international relations. Recently, China's foreign policies are responding to international challenges and they are constantly seeking to improve China's status (Lanteigne 2009). Xi Jinping's foreign policies are in line with his predecessor's principles on 
foreign policy. Xi has expanded these principles by including the Chinese diaspora, people to people relations, creating multiple strategic platforms, and the formation of a China-centered economic bloc (Brady 2017). It appears that China is directing by persuasion and cooperation, seeking peaceful development and coexistence. Chinese foreign policy employs 'four no-s' which include: no hegemony, no power politics, no alliance in terms of military, no race for arms (Cossa 1999). China's foreign policy features a priority for negotiation, cooperation rather than any means of force, which is considered soft strategy to regulate foreign relations.

States can exercise power in international relations. Power is the ability to influence others to get what one wants. The practice of power depends on the degree of intensity. It can be used as a manner of co-option or coercion. The aspects of both co-option and coercion is to get a desirable outcome. Nye first coined the term of soft power in 1990. According to Nye (2004), soft power is the ability to get the outcomes of what its possessor wants by persuading others, rather than commanding a payoff. It may be addressed as 'the second face of power' $(2004,5)$. Nye states that it is simply another form of power as it is the ability to shape the preferences of others. It is the degree of ability to move people by arguments. It does not depend on hard power, such as command or threat. Legitimacy is the core of soft power. If a country's action is legitimized in the eyes of another, then it will encounter less resistance to gain followers. However, soft power has its limitations. The effectiveness depends on the context and on the willingness of interpreters and receivers to understand it (Nye 2004). According to Gray (2011) soft power is the ability to achieve influential means by avoiding military and economic muscle. In the case of sudden decisions, soft power and its effects are unpredictable. It does not lend itself to measure the action or adjustment, but it must be more potent (Gray 2011). Some states, like Canada, do not define soft power, but avoid the use of armed forces as a means to exercise soft power (Smith-Windsor 2000). A state can influence others by using its ability to apply different degrees of strengths. It is only considered to be soft power if a state can gain support from others without the use of force; if force 
is used it is considered hard power. The methods of persuasion do not guarantee the desired outcome, because the outcome depends on the receivers, who have no hard and fast rules or pressure to do what the other wants.

Scholars argue that culture is the core of Chinese soft power. In recent years, China has expanded its cultural soft power resources. The influence of Chinese soft power can be observed. Despite intense interest, China's soft power policies are not comprehensive and remain ad hoc, primarily because it is reacting to and aiming to counter negative perceptions and seeking to avoid confrontation (Glaser and Murphy 2009). Kivimaki (2014) stated that if Chinese soft power strategies are evaluated according to China's objectives, then these strategies are well served. Its soft power is focused on developing relationships with others and cooperation, rather than seeking to establish itself as a hegemony. According to Zhang (2010), Chinese soft power seeks economic and political advantage in international relations. Chinese soft power has a circle of influence model which can be seen in its foreign policies and the response based on international reaction (Zheng and Zhang 2012).

Foreign policy is a stance adopted by the state to pursue the national interest, while diplomacy is a process to communicate with foreigners to achieve national goals. Diplomacy is a process of communication that takes place between individuals. Diplomacy is a mediator for managing international relations using negotiation and the transfer of information as methods (Sharp 2009). Traditional hierarchical structures of diplomacy have been undermined by the information age, particularly in communication. Public diplomacy allows people to have direct relations and communications with other countries. The context of dialogue includes ways to set up meetings, discover relations, and stay in touch through mutual understanding. Public diplomacy gives more opportunities for communication including debates and dialogue (Riordan 2004). This type of communication is an attempt to appeal to other nations. 


\section{Methods}

Mark Leonard $(2002,10)$ conceptualized public diplomacy as a grid of three rows and three columns. Leonard characterized three dimensions of public diplomacy activities to include a political, economic and societal sphere. Each of these spheres each carries different weights at various periods and in different contexts (Leonard 2002). The dimensions carry weight for foreign public communication (Leonard 2002b). Communicating with others helps to increase familiarity, increase appreciations, engage people, and achieve legitimacy. A state must have the ability to approach situations in a reactive way, a proactive way, and maintain relations in the international arena, due to different contexts. Sometimes communication depends on a condition (war/tension), sometimes it depends on an objective (persuading others). Aside from this, the time-span of communication also has implications on relationships. Mark Leonard has focused his work on all the previously mentioned issues in the dimensions of public diplomacy. Four kinds of soft power tools like cultural institutes, international events, 'financial aid for researchers and students', and media will be discussed in detail using the three dimensions of public diplomacy communication means: daily communication, strategic communication, and long-term relationship building communication (Leonard 2002, 10; Nye 2004, 107). Daily communication is reactive and takes place within hours or days. Strategic communication is proactive and can achieve campaign planning within weeks or months. Long-term communication depends on relationship building and takes years for a return (Leonard 2002, 11).

I will focus on the Confucius Institute, which is a cultural institution, because it is an influential institution with establishments all around the world. For international events, I will focus on the Belt and Road Initiatives Summit 2017. The Belt and Road Initiative has already generated political scholarship and made ripples in international relations within the twenty first century. From the financial aid for researchers and student's category, I will focus on international students who receive scholarships to study in China, because this type of individual has direct gains and there are long-term 
implications from this type of exchange. For mass media, I will focus only on CCTV, because it is easily accessible to audiences around the world. The discussion is comprised of two sections. First, it begins with an introduction of four Chinese soft power tools, and how they convey China's interest. Second, this paper assesses the rationality for employing different kinds of tools and their effectiveness in terms of foreign communication. The main source of information for this paper comes from a collection of secondary sources like journals, websites, and articles. This paper follows a qualitative research approach.

\section{Analysis and Discussion}

Tools of Soft Power

The Confucius Institute. In June 2004, the Confucius Institute began as a pilot project in Uzbekistan and was later fully established as an institute with its first location in South Korea (Starr 2009). The Confucius Institute was initiated by the 'Office of Chinese Language Council International', this is the official English translation. The Confucius Institute headquarters is known as Hanban. Its main goals are to teach Chinese, provide training for Chinese language learners and teachers, and administer international Chinese language examination the HSK [Hànyǔ Shuǔpíng Kăoshì 汉语水平考. This is the Chinese proficiency language test]. The annual report of the Confucius Institutes in 2017 gives some insight to the features of this organization. From the beginning to by the end of 2017, there are 525 Confucius institutes, 1113 Confucius classrooms in 146 countries across the world and more than 30 million examinees have taken the global Chinese language proficiency test. It has developed 852 sets of indigenous teaching material covering 80 languages.

Zaharna (2014) examines the Confucius Institute's communication approach using a three-fold typology: network structure, network synergy, and network strategy. In the network structure, the Confucius Institute 
represents a high-level coordination. For example, at an opening ceremony the host partner attends an official meeting to negotiate exchanges and research collaboration for students and faculty. In the network synergy, it is actively incorporating diversity when building internal relationships and external coalitions. In the network strategy, the impact is on value added knowledge creation, promoting language and culture, and emphasizing cultural activities (Zaharna 2014). Through building intercultural communication and relationships, the Confucius Institute is working towards establishing soft power (Paradise 2009). Lee (2008) notes the inherited cultural soft power is considered to be a cornerstone of economic progress and is creating amicable relationships.

Belt and Road summit 2017. The Belt and Road Initiative (originally 'One Belt One Road') was launched by China in 2013. It has two forks, often referred to as 'The Silk Road Economic Belt' and 'The 21st-Century Maritime Silk Road'. It hopes to connect more than 65 countries from three continents by building six economic corridors (CBBC 2015).

The Belt and Road forum for international cooperation (it is also known as the 'Belt and Road summit'), was held on May 14-15, 2017. It was the first highest level forum of its kind since the Belt and Road Initiative was proposed in 2013. More than 1,500 delegates from over 130 countries, including 29 world leaders, attended the two-day summit in Beijing (Tiezzi 2017). China used the forum to build an efficient cooperation platform, to create a closer partnership network, and to balance an international governance system (Xinhua 2017). Lei (2017) states that the major outcomes of the forum were that China signed a memorandum of understanding with 11 countries and cooperation documents with 9 international organizations. It has produced economic and trade cooperation agreements with 31 countries. The forum has financial backing by the Chinses government to support various projects. China also agreed to work towards a South-South cooperation, poverty alleviation, exchange program, and health care, and rehabilitation project to campaign the Belt and Road initiative (Lei 2017). 
The Belt and Road summit has potential to change the mindset of delegates. One in particular, is the Chief Minister of Khyber Pakhtunkhwa who created a hurdle for sharing benefits from the China-Pakistan Economic corridor in Pakistan. When the Chief Minister realized the significance of the corridor under the Belt and Road initiative, he participated in the summit with cooperation in mind (Chawla 2017). Pakistan signed a Belt and Road agreement in that forum without any domestic political concern.

CCTV. CCTV was originally launched as Beijing Television in 1958. In 1978, it was renamed as CCTV and they first broadcasted their international channel CCTV-4 in 1992. The broadcasting program was in Chinese. CCTV 9 aired in English in 2000, and in 2010 CCTV-9 became CCTV-news or, 'CCTV-N'. The channels of CCTV now broadcast in English, French, Spanish, Arabic, Russian, and Chinese. These channels also have a regional center. Since 2010, the regional production centers of CCTV are in Washington DC, USA, and in Nairobi, Kenya. In addition, CCTV has five central bureaus and 63 correspondents stationed overseas. CCTV has built connections with 279 organizations and developed 373 projects with foreign media. The aim of these connections is to broadcast Chinese programs through foreign media. The use of broadcasting as a tool of soft power has a major impact on international communication and audiences (Rawnnsley 2015). Under CCTV, all six language channels were relaunched as CGTV (China Global Television Network) on December 31, 2016. Including other English language media outlets such as CGTN, all serve as a means of soft power. President Xi Jinping, urged in a congratulatory letter for the news media to "tell China stories well, spread China's voice well, let the world know a three-dimensional, colorful China, and showcase China's role as a builder of world peace'(Hindustan Times, 2016). China is using the advancement of the information age to persuade and influence the foreign public (Kalathil 2011). According to Zhao,(2016) the media has extended China's ability to express itself as a responsible power, express its policies and to gain feedback about China's global image to counter these claims. 
International Students. China's financial aid for education offers scholarships to foreign students to study in China. Chinese financial aid for education and training is based on the principle of non-intervention in domestic politics and offers the Chinese development experience for recipient countries, particularly students coming from African countries. China's financial aid for education is well perceived (Yang and Ma 2015). In 2016, China was the most popular destination of overseas studies with over 442,773 international students from different countries and regions (IIE 2017). The ministry of education in China announced 'The National Outline for Medium and LongTerm Educational Reform and Development (2010-2020'. According to this plan, the Chinese government has proposed several policies, such as increasing scholarships to attract more international students to further increase international exchange.

The Chinese Government Scholarship program is the most effective mechanism of official development assistance (ODA), which is to spread goodwill and strengthen soft power. The scholarship has played a pivotal role in promoting and developing a positive long-term friendly relationship between China and recipient countries (Dong and Chapman 2008). Chinese universities have recruited more international students to improve its national education standards to be on par with the West and scholarships targeting international students (Yaoti 2016). China is recruiting more international students for political and cultural issues rather than for revenue. Offering scholarships is a strategy to attract international students from different parts of the developing and the developed world (Ahmad and Shah 2018). China's international student recruitment strategies uses education to build soft power and enhance its national image.

Rationality to using different soft power tools

Daily communication refers to immediate responses for particular issues, which are important to overcome crises. News media is one form of daily communication, as information can be transferred 24/7 through news media outlets (Leonard 2002,112). States have to respond to issues in real time and 
if necessary, follow-up with an appropriate action. Receiving up to date information quickly can provide a more holistic reality to audiences. Information is accessible to the foreign public with live broadcasts. Media have an important role regarding responses to issues through advocacy, monitoring, acknowledgment, and reputation enhancement.

The West and China continue to pursue their own current strategies in geopolitics, and the peril is likely to endure (Talmadge 2018). Haass (2018) notes China's rise can influence a dominating regime, like clashes with other regional powers like India, which could lead to a conventional nuclear competition. Meanwhile, China's rise poses a challenge for itself as its own manager of responsibility, its position to advance its national interest and to avoid engendering misperceptions among various audiences (Xiaoyu 2017). The evidence mentioned above suggested that a daily communication system is crucial to disseminate information about China's own position to international audiences to reduce tension. China has employed CCTV as a soft power tool to respond to issues within a short time frame. The following three incidents, which all took place over three consecutive years, will provide insight on the use of CCTV as a method to respond to current events. These three incidents are:

(a) In 2016, the UN tribunal ruled over the South China Sea, and the South China Sea has attracted a large following in international politics. When disputes over the South China Sea heightened, CGTN-America broadcasting played a pivotal role in reinforcing China's position and reaction (Philips, Holmes and Bowcott 2016; CGTN 2016);

(b) In 2017, Doklam issues, a border dispute, broke out between China and India. The Indian media claimed the Chinese media appears to have sounded its battle bells against India over the escalated Doklam issues (Krishnan 2017). On the other hand, Chinese TV channels carefully disseminated the Doklam issues in a manner that seeks to maintain regional stability (Scott 2017);

(c) In 2018, the United States and China faced-off in a 'trade war'. Washington stated that if the talk at the G-20 summit, which took place in 
Argentina, proved unsuccessful then tariffs would be raised from 10 to 25 percent. This was taken as a signal for an escalating international trade situation. Meanwhile Chinese state TV mentioned negotiations would continue and hinted there would be space for co-operation (McDonell, 2018). CCTV has provided a space for China to reinforce its national goals and to mediate with others. By mediating concerns, CCTV conveys information which can help foreign audiences to find a logic of discourse from China's perspective. In addition, they organized a talk-show with a panel featuring experts from diverse backgrounds. This talk show creates room for dialogue and mediation. CCTV has shown itself as a platform for immediate response to mediate escalating situations.

Strategic communication has a proactive role in process and purpose. It conveys a set of information to others for a positive reception. Developing 'a set of theme or agenda' is crucial in strategic communication to advance a particular policy (Nye 2004, 108). Implementing a policy requires a state to persuade potential followers. Strategic communication develops an agenda, and in a series of systematic events and opportunities, reinforces this agenda to persuade the public (Leonard 2002b). Campaigning a set of agenda can change the perceptions of the actor and gain positive foreign attention (Leonard 2002, 4).

International events are a platform where a set of agendas can be produced to the foreign public. It is an avenue for face to face negotiation and renegotiation with parties. Media is another tool for systematic agenda promoting. The agenda of the campaign might vary from place to place and from audience to audience with respect to different geo-political space and cultures. Media is a platform for disseminating these campaign agenda and receiving public opinion. International students are also a medium for strategic communication. When students live abroad, they become aware of their host country's campaigning agenda, as well as the rest of the world's perspective. International students can relay their experiences abroad with people of their home country, and thus, their roles go from being students to 
being local delegates for their native country. International students can act as advocates on behalf of the host country when communicating with others in their home country (Yun and Vibber 2012). They can function as de facto micro-ambassadors to the members of their home country.

Under Xi Jinping, a number of foreign policies were launched and one such example is the Belt and Road initiative. It is important to persuade other nations to implement the Belt and Road initiative on a full scale. In order to promote the Belt and Road initiative, China has made use of several of its soft power tools. Let's see how China employs its soft power tools to campaign the agenda of the Belt and Road Initiative.

First, China uses the media to promote Belt and Road Initiative. The China Global Television Network has broadcasted many episodes of their series titled, 'One Belt One Road Documentary: Common Fate' (road of connectivity, energy ties, road to prosperity, finance and connectivity, and building dreams). These episodes promote a set of themes for Belt and Road initiative (CGTN 2016). China Global Television Network hosted various talk shows featuring both critics and supporters of the Belt and Road initiative. For example, a program titled 'The Point' held a discussion with a group of panellists, who discussed both the advantages and disadvantages of the Belt and Road initiative.

Second, China has expanded their scholarship program for international students to study in China. Recently, China announced the Belt and Road initiative Scholarship, where each year 10,000 scholarships will be available for any recipients from any of the countries participating in the Belt and Road initiative (The State Council 2015). China has expanded exchange programs through training programs and vocational skill development, and management programs. In the Belt and Road initiative region, 2500 young foreign scientists were offered a one-time short-term research visit, and 5000 foreign professionals will be trained in China (Lei 2017). These exchange programs are a way to promote the agenda of the Belt and Road Initiative. Third, China has hosted international events related to the Belt and Road Initiative, such as the 'Belt and Road summit 2017' in Beijing. This event 
intended to introduce the Belt and Road concept and to inform all potential participants to reach consensus. According to the Ministry of Foreign Affairs, the theme of the summit is a 'win-win development'. China chose this theme purposefully to demonstrate itself as an open-minded collaborator for mutually benefitting development opportunities. There was a six parallel panel discussion, series of high-level meetings at the summit. It is a major platform for current and prospective stakeholder to rationalize their views and difficulties regarding Belt and Road initiative. The summit is framed in a positive manner that reflects China's Belt and Road agenda.

Long-term communication refers to building relationships that are long lasting. These relationships take time to build, and to have sustainable relationships there needs to be mutual trust and respect. Frequent contact and interaction of people can enhance others' appreciation for one's country in the long run. A relationship built on trust and appreciation of certain values relies on a reciprocal process. A relationship that is not reciprocal can be unsustainable. Scholarships and exchange programs, the influence of media in building relationships have long-term effects (Nye 2004, 109). International students have opportunities to get a deeper understanding of their host country's core values by living in the host country and engaging with locals. These students return to their home country with a sophisticated idea about their host country's strengths and weaknesses. In return, the host country's citizens have opportunities to understand the values of the international students' home countries. The relationship between international students and their host institution can be continued by creating alumni associations (Leonard 2002, 20-21). Similarly, cultural institute also has some similar effects. Learning a second language has impacts on personal and social relationships because language is a process of transferring knowledge and in this case, it is the knowledge of intercultural and academic exchange ( $O^{\prime}$ Brien, 2017). Cultural institutes use cultural relations to build relationships because through mutual understanding of cultural differences cultural institutes can better serve national interest abroad (Melissen 2005, 23). The administrators 
and teachers of cultural institutes play a role in the process of building relationships as they make connections with other organizations and locals. International students are the most effective instruments for building enduring relationships and learning a second language (like, student can learn Chinese at a Confucius Institute in their home country) has crucial impacts on the mind (Leonard 2002, 20; Cull 2009, 37-38).

Students who come to China to study learn a good deal about China and Chinese culture. After graduation, many of these students, upon their return to their home country, end up in positions that may influence policymaking towards China. In turn, they may influence policies to be more favorable to China. We can see this taking place in the relationship between China and South Korea. In spite of the geopolitical discourse between China and South Korea, exchange students and economic issues impact the relationship between these two nations (Kurlantzick 2007). Confucianism plays an important role to higher education in Korea (Lee 2006). Again, international students studying in China are exposed to a variety of cultural exchanges and they all benefit from this wide cultural exposure. As international students are exposed to life in China, they often form a different perspective of China's national image through conversations with other international students and local Chinese. This is perhaps more effective to creating a world of mutual understanding for international cooperation than simply academic research and learning in the classroom.

Moreover, the Confucius Institute's primary goal is to teach Chinese as a second language in a foreign country. This creates a path to engage with individuals who are non-Chinese or a non-state actor (Harting 2014). Cultural relations are important to building relationships based on mutual understanding rather than mere agenda-based campaigns, impacting long term communication rather than short term, and ultimately wining the hearts of other nations. 


\section{Evaluations of tools}

Effective foreign public relations rely on two-way communication that involves dialoguing (Nye 2004, 111). CCTV has the potential to transition from a monologue to a dialogue. The lack of international audience and a strong government interference are major flaws of Chinese broadcasting (Nelson 2013). In order to further manifest China's soft power through CCTV, there should be stronger information management for both domestic and international audiences (Lee 2013).

As a soft power tool, the Belt and Road Summit has had influences in improving dialogue. China has hosted some international events for the Belt and Road initiative. However, these events have not had such a positive appeal to India, a big country in South Asia. India disagrees with the construction of the China-Pakistan economic corridor and did not participate in the summit. However, the Belt and Road made appeals to other South Asian countries like Pakistan and Sri-Lanka. One major criticism of the Belt and Road initiative is that it favors Chinese companies which serve Beijing's geopolitical goals (Suokas 2018).

Teaching languages in the Confucius institute mostly operates in a monologue way. The Confucius Institute is often seen as promoting party propaganda in foreign countries (Harting 2015). As such, the critique of the Confucius Institute is that it has little association with popular culture (Zhe 2010). Zhe stated that the Confucius Institute is mostly focused on traditional culture which is less attractive to the younger generations. Without promoting popular culture abroad, its soft power remains limited (Zhe 2010). As a soft power tool, scholarship and inbound international students belongs to the practice of a two-way communication. Wu (2018) stated that the way China's institutional education policy is implemented needs improvement. In order to better appeal to developed countries and to potential students from different ideological roots, it should improve living conditions, reduce ideological discourse in the classroom and engage in more oversees promotion (Wu 2018). 
The aim of foreign public communication is to manage the international community in a way that facilitates the achievement of the state's foreign policy objectives. Due to globalization, various types of tools are getting priority in foreign public communication, rather than the traditional institutes. As well as, the mode of communication not only rests on talking but also on listening. If the communication will not resonate with mode of communication, there is minimal or no possibility to achieve the expected outcome from public diplomacy (Cull 2009). Listening to others, integrating public opinion with policy, engaging with the foreign public, credibility, communicating into a matrix rather than a single mechanism, and holding potential to address issues in wider range are important in public diplomacy (Cull 2010). An effective mechanism to understanding other countries needs, correcting misperceptions, looking for areas to work together, and promoting national interest is crucial in foreign public relations. The weakness and strength of tools can impact the whole process of communication. The choice of tools and the effectiveness of those tools are important in achieving the goals of foreign public communication. Each soft power tool mentioned above has their own limitations. For daily communication, media is relatively more useful because it captures the reaction and provides a response strategy. Other kinds of tools cannot respond to issues as quickly nor reach a vast audience in as short of a period, like the media can. For strategic communication, international events have a relative purpose through agendasetting. The media and international students can also contribute a certain level to the promotion of themes and agenda-setting. For building long-term communication, engaging overtime is an important factor to building trust and respect. Exchange programs and cultural institutes can offer comparatively more reciprocal engagement with people to create mutual understanding. Moreover, media can set the foundation for long-term communication (Leonard 2002, 20). 


\section{Concluding remarks}

China uses different soft power tools to influence international relations. Four categories of cultural soft power tools have been examined following the three dimensions of public diplomacy. Their impacts on dimensions are summarized hereunder.

The Confucius Institute (cultural institute) has an advanced role on long-term communication. The approach of greater exchange as well as collaboration on teaching language and culture can build better relationships based on mutual understanding of cultural differences.

The Belt and Road initiative summit (international events) plays a role in strategic communication. It can promote a comprehensive set of agendas and reinforce them by conducting a series of discussions to persuade current and prospective stakeholders.

CCTV (media) is a crucial tool for daily communication and strategic communication. It works both as a reactive and proactive platform for communication. It is relatively useful for immediate issue management in a 24 hours news cycle. It also generates public awareness of the national agenda. International students (financial aid for researchers and students) are relatively important for long-term communication. Their frequent engagement with locals is a process of transferring knowledge. Exchange programs can offer mutual and reciprocal attempts to create mutual understanding. Creating an alumni association can be a way to maintain these relationships in the long run.

Communication is essential in international relations, and success relies on whose story wins (Nye 2010). Effective Communication can lead to a victorious story. The vacuum of information/communication due to weakness of communicative tools, other could be rushed in to fill it. China faces problem due to language and cultural gaps in communicating with the international community. China has set some themes like peaceful rise, harmonious world, and strategic opportunities that are involved in the 'objective of communication' with foreign countries. Those themes lack an exact English translation to convey their real meaning (Wang 2008, 266). This 
kind of problem may impact communication tools during strategic communication, while campaigning themes take the focus. When communicating with geographically and culturally distant stakeholders, the message needs to be formulated in the light of their social norms and values. Besides, foreign public communication is a transnational issue, whereas stakeholder identification can be troublesome due to lack of knowledge, channel, and legitimacy. Communication tools can facilitate understanding of the stakeholders' interest, and mobilization and facilitation concerns.

Moreover, foreign public communication is played out with political/military, economic and cultural spheres. China is a rising power, with its foreign public communication getting priority in all three spheres. For example, the "China threat theory' has negative implications on China's image. The nation must communicate with the political realm to pursue its position. China is the second largest economy in the World. The nation must deal with developing, underdeveloped and developed countries. China must also give emphasis on the economic sphere. Again, Chinese culture bears the notion of harmony and peace. It thinks interpersonal relations are important for a harmonious world and building relationships. Emphasis on the cultural realm is also crucial for China. Aside from that, relationship building can take place across the political, economic, and cultural sphere (Leonard 2002, 18). China employs various tools like diaspora, theme city in different countries, sending a substantial number of peacekeepers to the United Nations peace keeping mission to 'win heart and minds' of others through more engagement and communication. China wants to be seen as a stable economic partner, a responsible member in the international community, and to seek a respected position of its ancient culture and political system (d'Hooghe 2005). A combined effort of communication can facilitate achievement of the abovementioned objectives. If tools are not served effectively with communication modes (two-way street) and dimensions, then the effort will not bring the desired return. It could lead a country like China to employ various tools in foreign public communication. 
According to Gilboa (2008, 73), governments have a close link with crisis issues, which may have an impact on some instruments like advocacy, broadcasting, lobbying and cyber. However, governments are also partially or remotely linked with intermediate and long-term communication. In the before mentioned perspectives, branding, exchanges, corporate, and diaspora are considered as applicable instruments (Gilboa 2008). Sometimes, linking with government can increase critics of concern of these tools. In foreign public communication, all tools are not effective, and some tools are effective for only particular audiences (Harting 2016). It is hard to measure which tool can effectively serve all dimensions in foreign public communication.

\section{Acknowledgement}

The author is grateful to the two anonymous reviewers for their valuable recommendations on earlier draft of this article. The author extends his/ thank to the Ministry of Commerce of the People's Republic of China (MOFCOM scholarship) for funding to pursue a Ph.D. in political theory since 2016.

\section{References}

Ahmad, Ahmad Bayiz, and Mahsood Shah. 2018. 'International Students' Choice to Study in China: An Exploratory Study'. Tertiary Education and Management, April, 1-13. https://doi.org/10.1080/13583883.2018.1458247.

Brady, Anne-Marie. 2017. 'Magic Weapons: China's Political Influence Activities under Xi Jinping.' Accessed 08 January 2019. https://www.wilsoncenter.org/sites/default/files/magic_weapons. pdf.

Chawla, Muhammad Iqbal 2017. ‘One Belt One Road Summit 2017 and its Implications for CPEC: An Overview'. South Asian Studies, 32 (2): 277 $-284$.

China-Britain Business council (CBBC). 2015. 'One belt one road-A role for UK companies in developing China's new initiative- New opportunities in China and beyond'. Accessed 12 December 2018 
http://www.chinagoabroad.com/en/article/a-role-for-ukcompanies-in-developing-china-s-new-initiative.

CGTN 2016. 'Explaining the south China sea'. Accessed 28 December 2018, https://america.cgtn.com/2016/07/02/explaining-the-south-chinasea.

CGTN 2016. 'One Belt One Road Documentary Episode One: Common Fate'. Accessed 10 December 2018, https://www.youtube.com/watch?v=_NtprkECCiU.

Confucius Institute Annual Development Report 2017. Confucius Institute headquarters (Hanban). www.hanban.edu.cn.

Cossa, Ralph A. 1999. 'U.S.-Japan-China Relations: Can Three Part Harmony Be Sustained?' The Brown Journal of World Affairs 6 (2): 77-94.

Cull, Nicholas, J. 2009, 'Public Diplomacy: Lesson from the Past', 42-46, USC Center on Public Diplomacy at the Annenberg School, University of Southern California, Los Angeles: Figueroa Press.

Cull, Nicholas J. 2010. 'Public diplomacy: seven lessons for its future from its past', Place Branding and Public Diplomacy 6:11-17.

Dong, Lili, and David W. Chapman. 2008. 'The Chinese Government Scholarship Program: An Effective Form of Foreign Assistance?' International Review of Education / Internationale Zeitschrift Für Erziehungswissenschaft / Revue Internationale de l'Education 54 (2): 15573.

d'Hooghe, Ingrid. 2005. 'Public diplomacy in the people's republic of China.' In The new public diplomacy-soft power in international relations, edited by Jan Melissen, 93-94. New York: Palgrave Macmillan.

Flew, Terry. 2016. 'Evaluating China's Aspirations for Cultural Soft Power in a Post-Globalisation Era'. Media International Australia 159 (1): 32-42. https://doi.org/10.1177/1329878X16638743.

Gilboa, Eytan. 2008. 'Searching for a Theory of Public Diplomacy'. The ANNALS of the American Academy of Political and Social Science 616 (1): 55-77. https://doi.org/10.1177/0002716207312142.

Glaser, Bonnie S. and Melissa E. Murphy. 2009. Soft power with Chinese characteristics the ongoing debate. Accessed 12 November 2018. https://csis-prod.s3.amazonaws.com/s3fspublic/legacy_files/files/media/csis/pubs/090310_chinesesoftpowe r_chap2.pdf.

Gray, Colin S. 2011. Hard Power and Soft Power: The Utility of Military Force as an Instrument of Policy in the 21st Century. SSI Monograph. Carlisle, Pa: Strategic Studies Institute, U.S. Army War College. 
Harting, Falk. 2014. 'New public diplomacy meets old public diplomacy-the case of China and its Confucius institutes.' New Global Studies 8 (3): 331-352.

Hartig, Falk. 2015. 'Communicating China to the World: Confucius Institutes and China's Strategic Narratives'. Politics 35 (3-4): 245-58. https://doi.org/10.1111/1467-9256.12093.

Harting, Falk. 2016. 'How China understand public diplomacy: the importance of national images for national interests.' International Studies Review 18 (4): 655-680.

Haass, Richard. 2018. 'How a World Order Ends and What Comes in Its Wake'. Foreign Affairs. Accessed 05 December 2018. https://www.foreignaffairs.com/print/1123411.

Hindustan Times. 2016. 'China's CCTV launches global 'soft power' network to extend influence'. December 31, 2016, Accessed 25 December 2018 https://www.hindustantimes.com/world-news/china-s-cctvlaunches-global-soft-power-network-to-extend-influence/storyQPCoWTJQmmAOxJ5OhMiMEO.html..

Institute of International Education (IIE). 2017. 'International students', Accessed 17 December 2018. https://www.iie.org/Research-andInsights/Open-Doors/Data/International-Students.

Kalathil, Shanthi. 2011. 'China's Soft Power in the Information Age: Think Again'. ISD working papers in new diplomacy. Accessed 12 December 2018.

https://isd.georgetown.edu/sites/isd/files/Kalathil_Chinas_Soft_P ower.pdf.

Kivimaki, T. 2014. 'Soft Power and Global Governance with Chinese Characteristics'. The Chinese Journal of International Politics 7 (4): 42147. https://doi.org/10.1093/cjip/pou033.

Krishnan, Ananth. 2017. 'Beijing does not fear war: Is China earing for battle over Doklam Standoff?' India Today, July 18, 2017. Accessed 05 November 2018 https://www.indiatoday.in/world/story/doklamstandoff-china-india-sikkim-border-standoff-pla-beijing-10248552017-07-18.

Kurlantzick, Joshua. 2007. 'China offensive- How China's Soft Power Is Transforming the World'. A New Republic Book, 94. New Haven and London: Yale University Press.

Lanteigne, Marc. 2009. Chinses Foreign policy: An introduction. New York: Routledge. 
Lee, Claire Seungeun. 2013. 'China's International Broadcasting as a Soft Power Ma(r)ker: Its Market Formation and Audience Making'. ERCCT Online Paper Series, EOPS No. 0027, European Research Center on Contemporary Taiwan.

Lee, Jeong-Kyu. 2006. 'Educational Fever and South Korean Higher Education'. Revista Electronica de Investigacion Educativa (REDIE), 8(1), https://files.eric.ed.gov/fulltext/ED491564.pdf. Accessed 02 December 2018.

Lee, Seung-eun. 2008. China's Cultural Diplomacy in the Hu Jintao Era: The Geocultural Role of the Confucius Institute. Accessed 15 December 2018 https://www.researchgate.net/publication/270895378 .

Lei, Wang 2017, BandR forum concludes in Beijing 270 concrete results, Accessed 08 May 2019 https://news.cgtn.com/news/3d49544f34677a4d/share_p.html.

Leonard, Mark. 2002. Public Diplomacy. The foreign policy Centre, London, UK.

Leonard, mark. 2002b. 'Diplomacy by other means.' Foreign Policy.' Washington Post. Newsweek interactive, LLC 1: 48-56.

McDonell, Stephen. 2018. 'US-China trade war: Deal agreed to suspend new trade tariffs.' BBC News, December 2, 2018. Accessed 28 December 2018 https://www.bbc.com/news/ world-latin-america-46413196.

Melissen, Jan. 2005. 'The New Public Diplomacy: Between Theory and Practice'. The New public diplomacy: soft power in international relations, edited by Jan Melissen, 3-27. New York: Palgrave Macmillan.

Ministry of Foreign Affairs, China, 'Win-win Development is the Theme of the International Cooperation Summit Forum on the 'Belt and Road' $\begin{array}{llll}\text { Initiative' } & \text { Accessed } & 23 & \text { May }\end{array}$ https://www.fmprc.gov.cn/mfa_eng/wjbxw/t1443383.shtml.

Nelson, Anne. 2013. CCTV's International Expansion: China's Grand Strategy for Media? $\quad$ Accessed $01 \quad$ December 2018 http:/ / www.centerforinternationalmediaassistance.org/wpcontent/uploads/2015/02/CIMA-China-AnneNelson_0.pdf.

Nye, Joseph S. 2004. Soft power- the means to success in World politics. 5-18. New York: Public Affairs.

Nye, Joseph S. 2010. The new public diplomacy. Unclassified U.S. Department of state, case no. F-2014-20439, Doc No. C05767159, Date: 08/31/2015.

O'Brien, Mary G. (principal investigator). 2017. Literature Review on the Impact of Second-Language Learning. The Alberta Teachers' Association and The Canadian Association of Second Language Teachers. Accessed 12 
December 2108 https://www.caslt.org/files/media/news/Litreview-Impact-L2-Learning.pdf.

Paradise, James F. 2009. 'China and International Harmony: The Role of Confucius Institutes in Bolstering Beijing's Soft Power'. Asian Survey 49 (4): 647-669.

Phillips, Tom, Oliver Holmes and Owen Bowcott. 2016. 'Beijing rejects tribunal's ruling in South China Sea case'. The Guardian, July 12. Accessed $\quad 02 \quad$ December 2018 https://www.theguardian.com/world/2016/jul/12/philippineswins-south-china-sea-case-against-china.

Rawnsley, Gary D. 2015. 'To Know Us is to Love Us: Public Diplomacy and International Broadcasting in Contemporary Russia and China'. Politics 35 (3-4): 273-286.

Riordan, Shaun. 2004. 'Dialogued-based public diplomacy: A new foreign policy paradigm? Discussion papers.' Diplomacy 95 (November 2004), Neatherland institute of international relations Accessed 02 January 2019

https://www.clingendael.org/sites/default/files/pdfs/20041100_cli _paper_dip_issue95.pdf.

Roselle, Laura, Alister Miskimmon and Ben O'Loughlin. 2014. 'Strategic narrative: A new means to understand soft power'. Media, War and Conflict 7 (1): 75.

Scott, Christopher 2017. 'Chinese TV strikes a delicate balance on Doklam coverage'. AsiaTimes, August 05, 2017. Accessed 29 November 2018 http://www.atimes.com/article/chinese-tv-striking-delicatebalance-doklam-standoff-coverage.

Sharp, Paul. 2009. Diplomatic theory of international relations. p.13 and p.54. Cambridge university press.

Smith-Windsor, Brooke A. 2000. 'Hard power, soft power reconsidered'. Canadian military journal 1 (3): 51-56.

Starr, Don. 2009. 'Chinese Language Education in Europe: The Confucius Institutes'. European Journal of Education 44 (1): 65-82. https://doi.org/10.1111/j.1465-3435.2008.01371.x.

Suokas, Janne. 2018. 'China to host second Belt and Road forum in April 2019'. gbTimes, Accessed 20 May 2019, https://gbtimes.com/china-to-hostsecond-belt-and-road-forum-in-april-2019.

Talmadge, Caitlin. 2018. 'Beijing's nuclear option'. Foreign affairs 97 (6): 45.

Taylor, Philip M. 2010. 'Public diplomacy and the information war on the terror'. In Soft Power and US Foreign Policy -Theoretical, historical and 
S. Rahman. - China's Foreign Policy and its Choice for Cultural Soft Power: The Tools

contemporary perspectives, edited by Inderjeet Parmar and Michael Cox, 152-164. London and New York: Routledge.

Tiezzi, Shannon 2017, 'What did China accomplish at the Belt and Road Forum?', The Diplomat, May 16, 2017, Accessed on 20 May 2019 https://thediplomat.com/2017/05/what-did-china-accomplish-atthe-belt-and-road-forum/

The State Council. 2015. 'Action plan on the Belt and Road Initiative'. Accessed 21 December 2018. english.gov.cn/archive/publications/2015/03/30/content_28147508 0249035.htm.

Wang, Yiwei. 2008. 'Public Diplomacy and the Rise of Chinese Soft Power'. The Annals of the American Academy of Political and Social Science 616: 257-73.

Wu, Hantian. 2018. 'China's International Student Recruitment as “OutwardOriented" Higher Education Internationalisation: An Exploratory Empirical Inquiry'. Compare: A Journal of Comparative and International Education, March, 1-16. https://doi.org/10.1080/03057925.2018.1444469.

$\mathrm{Pu}$, Xiaoyu. 2017. 'Controversial Identity of a Rising China'. The Chinese Journal of International Politics 10 (2): 131-49. https://doi.org/10.1093/cjip/pox004.

Xinhua 2017. 'China focus: Belt and Road forum agenda set' Accessed 20 May 2019, www.xinhuanet.com//english/2017-04/18/c_136218408.htm.

Yang, Rui and Jinyuan Ma. 2015. 'China's International Aid in Education: Development, Determinants and Discord'. Accessed 03 December 2018

https://www.researchgate.net/profile/Rui_Yang36/publication/28 3518107_Lessons_learnt_from_Asian_states'_transitions_from_aid_re cipients_to_donors_China's_international_aid_in_education_Develo pment_determinants_and_discord/links/56f1316608ae5c367d4a97a1. pdf?origin=publication_detail.

Yaoti, Ren. 2016. 'As China enrolls more overseas students to build soft power, locals find the process unfair'. Global Times, October 24, 2016. Accessed $26 \quad$ December 2018. http://www.globaltimes.cn/content/1013390.shtml.

Yun, Seong-Hun, and Kelly Vibber. 2012. 'The Strategic Values and Communicative Actions of Chinese Students for Sociological Korean Public Diplomacy'. International Journal of Strategic Communication 6 (1): 77-92. https://doi.org/10.1080/1553118X.2011.634864. 
Zaharna, Rhonda S. 2014. 'China's Confucius institutes: understanding the relational structure and Relational dynamics of Network Collaboration'. In Confucius Institutes and the Globalization of China's Soft Power, edited by Jain Wang, 9-31. Los Angeles: Figueroa Press.

Zhang, Weihong. 2010. 'China's Cultural Future: From Soft Power to Comprehensive National Power'. International Journal of Cultural Policy 16 (4): 383-402. https:// doi.org/10.1080/10286630903134300.

Zhao, Xin. 2016. 'A Review on China's Soft Power Projection through Its Transnational Media Institutions: Conveying Discourse of Economic Responsibilities in Media "Going-Out". For(e)Dialogue 1 (1): 27-39. https://doi.org/10.29311/for(e)dialogue.v1i1.530.

Zhe, Ren. 2010. Confucius Institutes: China's Soft Power? SIGUR Centre for Asia studies Policy Commentary - June 2010 Accessed 02 November 2018. https://www.risingpowersinitiative.org/wpcontent/uploads/policycommentary_jun2010_confuciusinstitute.pdf. Zheng, Yongnian, and Chi Zhang. 2012. "'Soft Power" and Chinese Soft Power'. In China's Soft Power and International Relations, edited by Hongyi Lai, 1st ed., 21-38. Routledge. https://doi.org/10.4324/9780203122099. 